\title{
Praktik Green Supply Chain Management (GSCM) pada UKM
}

\author{
Clora Widya Brilliana, Imam Baihaqi, dan Satria Fadil Persada \\ Departemen Manajemen Bisnis, Institut Teknologi Sepuluh Nopember (ITS) \\ e-mail: ibaihaqi@mb.its.ac.id
}

\begin{abstract}
Abstrak-Usaha Kecil Menengah (UKM) di Indonesia memiliki peran penting dalam banyak aspek ekonomi nasional. Salah satu penyebab polusi industri adalah kehadiran industri skala kecil dalam jumlah yang besar. Bentuk komitmen perusahaan untuk menjaga lingkungan, salah satunya dengan menerapkan rantai pasok yang lebih ramah lingkungan, yang disebut Green Supply Chain Management (GSCM). Namun praktik GSCM belum banyak diterapkan di negara berkembang, khususnya pada UKM. Penelitian ini bertujuan untuk mengetahui sejauh mana praktik GSCM diterapkan di UKM. Dari pengumpulan data menggunakan survei kuesioner didapatkan 41 data responden. Metode yang digunakan adalah analisis deskriptif dengan menghitung rata-rata dan proporsi skor jawaban 4 dan 5 pada setiap item indikator. Hasil penelitian ini didapatkan bahwa UKM manufaktur di Surabaya sudah melakuan beberapa praktik GSCM pada perusahaannya, meskipun tidak secara keseluruhan.
\end{abstract}

Kata Kunci-Green Supply Chain Managemet, Manufaktur, UKM.

\section{PENDAHULUAN}

$\mathrm{U}$ SAHA Kecil Menengah (UKM) di Indonesia memiliki peran penting dalam banyak aspek ekonomi nasional. Setiap kegiatan industri tidak hanya akan memberi dampak positif maupun negatif pada perekonomian, namun juga dampak lain yaitu lingkungan. Khususnya pada industri manufaktur yang lebih berpotensi menghasilkan limbah lebih banyak. Selain itu juga terdapat beberapa masalah lingkungan yang signifikan saat ini, di mana manusia memainkan peran penting dalam penyebabnya.

Terdapat beberapa masalah lingkungan yang signifikan saat ini, di mana manusia memainkan peran penting dalam penyebabnya, yaitu polusi, perubahan iklim, pemanasan global, penggundulan hutan, populasi berlebihan, limbah industri dan rumah tangga, hujan asam, lapisan ozon, rekayasa genetika, dan perluasan kota[1]. Naiknya konsentrasi Gas Rumah Kaca akibat penggunaan bahan bakar fosil yang menyebabkan perubahan iklim semakin tidak menentu. Peneliti The Met Office mengatakan bahwa suhu global tahun 2019 akan menjadi yang terpanas selama catatan lima tahun terakhir, yang mana bisa mencapai $1,10^{\circ} \mathrm{C}$ di atas tingkat praindustri[2]. Sehingga diperlukan tindakan cepat dari seluruh masyarakat untuk menurunkan emisi. Kasus pencemaran lingkungan akibat aktivitas industri di Indonesia juga banyak terjadi. Sungai Citarum yang memiliki kualitas air sangat buruk menurut parameter polusi, diakibatkan dari polusi limbah domestik dan limbah industri tekstil di sekitar kawasan
Tabel 1 . Kriteria UKM di Indonesia

\begin{tabular}{lll}
\hline \hline Klasifikasi & \multicolumn{1}{c}{ Kekayaan bersih } & \multicolumn{2}{c}{ Penjualan Tahunan } \\
\hline Mikro & Maksimal Rp 50 juta & Maksimal Rp 300 juta \\
Kecil & Rp 50 juta - Rp 500 juta & Rp 300 juta - Rp 2,5 miliar \\
Menengah & $\begin{array}{l}\text { Rp 500 juta }- \text { Rp 10 } \\
\text { miliar }\end{array}$ & $\begin{array}{l}\text { Rp 2,5 miliar }- \text { Rp 50 } \\
\text { miliar }\end{array}$ \\
\hline \hline
\end{tabular}

tersebut yang tidak dikelola. Serta buih putih yang muncul di Kali Bekasi menuju laut pada bulan September lalu, berasal dari limbah industri[3]. Dari berbagai masalah perubahan lingkungan tersebut, tentu akan memengaruhi kesehatan masyarakat yang tinggal disekitar wilayah industri yang mengalami penurunan kualitas lingkungan.

Tidak hanya perusahaan besar, UKM juga memiliki peran dalam menjaga lingkungan sekitar. Salah satu penyebab polusi industri adalah kehadiran industri skala kecil dalam jumlah yang besar [4]. Banyak industri skala kecil dan pabrik yang tidak memiliki modal yang cukup dan bergantung pada hibah pemerintah untuk menjalankan bisnis sehari-hari. Mereka sering lolos dari peraturan lingkungan dan mengeluarkan sejumlah besar gas beracun di atmosfer.

Kewajiban perusahaan untuk menjaga lingkungan sekitar, sudah tertulis dalam Undang-Undang No 3 Tahun 2014 Tentang Perindustrian pasal 30, yang mewajibkan perusahaan industri untuk mengolah dan memanfaatkan sumber daya alam secara efisien, ramah lingkungan, dan berkelanjutan [5]. Selain itu, sebagaimana pada pasal 79 dan pasal 80, perusahaan Industri wajib memenuhi ketentuan standar Industri Hijau yang disusun dan ditetapkan oleh menteri.

Komitmen perusahaan untuk menjaga lingkungan, salah satunya dengan menerapkan rantai pasok yang lebih ramah lingkungan, yang disebut Green Supply Chain Management (GSCM). Praktik GSCM merupakan penerapan prinsip-prinsip manajemen lingkungan untuk seluruh rangkaian kegiatan rantai pasokan, termasuk desain, pengadaan, manufaktur, perakitan, pengemasan, logistik, dan distribusi [6]. Namun praktik GSCM belum banyak diterapkan di negara berkembang, khususnya pada UKM. Perusahaan skala kecil menunjukkan tingkat implementasi GSCM yang lebih rendah dibandingkan dengan perusahaan skala besar dan menengah [7].

Dalam penelitian ini penulis membahas tentang sejauh mana praktik GSCM telah diterapkan pada UKM. Penelitian ini diharapkan dapat berkontribusi untuk menambah wawasan 
baru pada bidang penelitian terkait praktik GSCM. Selain itu penelitian ini juga penting dilakukan untuk menjadi masukan bagi pemangku kepentingan untuk menyusun strategi peningkatan UKM menerapkan praktik GSCM.

\section{LANDASAN TEORI}

\section{A. Usaha Kecil dan Menegah (UKM)}

Usaha mikro, kecil dan menengah masing-masing memiliki kriteria, berdasarkan kekayaan bersih dan hasil penjualan tahunan [8], seperti pada Tabel 1.

Berikut merupakan karakteristik yang dimiliki oleh UMKM menurut Undang-Undang No 20 Tahun 2008 tentang UMKM.

1) Sebagian usaha kecil ditandai dengan belum mempunyai status badan hukum.

2)Tidak adanya pembagian tugas yang jelas antara bidang administrasi dan operasi, karena kebanyakan industri kecil dikelola oleh perorangan yang merangkap sebagai pemilik sekaligus pengelola perusahaan, serta memanfaatkan tenaga kerja dari kerabat.

3) Rendahnya akses industri kecil terhadap lembaga-lembaga kredit formal sehingga mereka menggantungkan pembiayaan dari modal sendiri atau sumber-sumber lain seperti keluarga, kerabat, pedagang perantara, bahkan rentenir.

BPS Provinsi Jawa Timur mengelompokan sektor UKM menjadi sembilan, anatara lain: (1) pertanian, (2) pertambangan dan penggalian, (3) industri pengolahan, (4) listrik, gas dan air, (5) konstruksi, (6) perdagangan hotel dan restoran, (7) transportasi, (8) keuangan, dan (9) jasa-jasa [9]. Dari sektor-sektor tersebut, industri pengolahan berpotensi menghasilkan limbah lebih banyak daripada sektor lainnya dan akan banyak berdampak pada lingkungan [10]-[12]. Sehingga pada penelitian ini fokus pada UKM sektor industri pengolahan atau disebut dengan manufaktur.

\section{B. Supply Chain}

Supply chain (rantai pasok) adalah jaringan perusahaanperusahaan yang secara bersama-sama bekerja untuk menciptakan dan mengantarkan suatu produk ke tangan pemakai akhir [13]. Perusahaan-perusahaan tersebut biasanya termasuk supplier, pabrik, distributor, toko atau ritel, serta perusahaan-perusahaan pendukung seperti perusahaan jasa logistik. Pada suatu rantai pasok, terdapat tiga aliran yang perlu dikelola. Aliran tersebut adalah aliran barang/material, uang, dan informasi yang mana bisa mengalir dari hulu ke hilir dan juga hilir ke hulu.

Kesadaran pelaku industri akan pentingnya koordinasi yang lebih baik antar berbagai pihak, dalam menciptakan dan mengantarkan produk yang murah, berkualitas, dan cepat, melahirkan konsep Supply Chain Management (SCM). Kegiatan utama Supply Chain Management adalah : (1) kegiatan merancang produk baru (Product Development), (2) kegiatan mendapatkan bahan baku (Procurement, Purchasing, atau Supply), (4) kegiatan merencanakan produksi dan persediaan (Planning \& Control), (5) kegiatan melakukan produksi (Production), (6) kegiatan melakukan
Tabel 2. Profil Responden

\begin{tabular}{lcc}
\hline \hline \multicolumn{1}{c}{ Profil } & Frekuensi & Persentase \\
\hline Jabatan & & \\
Pemilik & 28 & $68 \%$ \\
Pengelola (manager) & 13 & $32 \%$ \\
\hline Total & 41 & $100 \%$ \\
\hline Lama bekerja & & \\
< 5 tahun & 12 & $29 \%$ \\
6 - 10 tahun & 16 & $39 \%$ \\
11 - 15 tahun & 6 & $15 \%$ \\
16 - 20 tahun & 6 & $15 \%$ \\
$>$ 20 tahun & 1 & $2 \%$ \\
\hline Total & 41 & $100 \%$ \\
\hline \hline & & \\
\hline \hline \multicolumn{1}{c}{ Profil } & Frekuensi & Persentase \\
\hline Sektor perusahaan & & \\
Makanan dan/atau minuman & 20 & $49 \%$ \\
Tekstil, pakaian, alas kaki, dan kulit & 10 & $24 \%$ \\
Produk kayu dan kertas & 5 & $12 \%$ \\
Lain-lain & 6 & $15 \%$ \\
\hline Total & 41 & $100 \%$ \\
\hline Hasil penjualan tahunan & & \\
Rp 300 juta - Rp 2,5 miliar & 35 & $85 \%$ \\
Rp 2,5 miliar - Rp 50 miliar & 6 & $15 \%$ \\
\hline Total & 41 & $100 \%$ \\
\hline Bentuk badan usaha & & \\
Tidak berbadan usaha & 13 & $20 \%$ \\
CV & 20 & $49 \%$ \\
UD & 41 & \\
\hline Total & & \\
\hline \hline
\end{tabular}

pengiriman/distribusi (Distribution), (7) kegiatan melakukan pengembalian produk/barang (Return)

Elemen-elemen dasar pada manajemen rantai pasok menurut Mentzer (2001) dalam Azari (2018), antara lain: (1) Sikap terintegrasi, yaitu sekumpulan kegiatan dari manajemen rantai pasok yang terkoordinir bersama; (2) Pembagian informasi secara mutual; (3) Pembagian risiko dan penghargaan secara mutual; (4) Kerjasama; (5) Memiliki tujuan dan fokus pelayanan pelanggan yang sama; (6) Proses yang terintegrasi; dan (7) Mitra untuk membangun dan menjaga hubungan jangka panjang [14].

\section{Green Supply Chain Manegement}

Green Supply Chain Management adalah konsep modern dari supply chain tradisional yang mana berbagai kegiatan, seperti pembelian hijau, desain hijau, penghematan sumber daya, pengurangan penggunaan bahan berbahaya, daur ulang produk, dilakukan untuk meminimalkan dampak lingkungan [15]. Praktik GSCM merupakan penerapan prinsip-prinsip manajemen lingkungan untuk seluruh rangkaian kegiatan rantai pasokan, termasuk desain, pengadaan, manufaktur, perakitan, pengemasan, logistik, dan distribusi [6].

Rujukan [16] mengklasifikasikan praktik GSCM berdasarkan kegiatannya ke dalam lima kategori, yaitu:

1) Intra-organizational environment management : mengacu pada praktik intra-organisasi seperti dukungan manajemen puncak, program kepatuhan lingkungan, dan kerja sama antar departemen untuk perbaikan lingkungan.

2) Product eco-design : proses struktural yang terdiri dari 
Tabel 3.

Analisis Deskriptif Statistik

\begin{tabular}{|c|c|c|c|c|}
\hline & $\begin{array}{ll} & \text { Pernyataan } \\
\end{array}$ & Mean & Std. Dev & \% skor 4-5 \\
\hline \multicolumn{5}{|c|}{ PR - Pembelian Ramah Lingkungan : Perusahaan kami .... } \\
\hline PR1 & memberikan spesifikasi desain terkait lingkungan kepada pemasok untuk barang yang dibeli & 3,68 & 0,93 & $66 \%$ \\
\hline PR2 & melakukan kerjasama dengan pemasok untuk merancang produk yang ramah lingkungan & 3,66 & 0,99 & $68 \%$ \\
\hline PR3 & bekerjasama dengan pemasok untuk tujuan ramah lingkungan & 3,93 & 1,03 & $68 \%$ \\
\hline PR4 & melakukan audit lingkungan terhadap manajemen internal pemasok & 3,32 & 1,19 & $59 \%$ \\
\hline PR5 & mengevaluasi praktik ramah lingkungan pada perusahaan pemasok & 3,49 & 1,08 & $66 \%$ \\
\hline PR6 & merupakan salah satu kriteria dalam pemilihan pemasok & 3,71 & 0,93 & $73 \%$ \\
\hline \multicolumn{5}{|c|}{ KP - Kerjasama Pelanggan Persyaratan Lingkungan : Perusahaan kami .... } \\
\hline KP1 & menerima masukan dari pelanggan untuk desain produk ramah lingkungan & 4,27 & 0,78 & $85 \%$ \\
\hline KP2 & melakukan kerjasama dengan pelanggan untuk produksi yang lebih bersih & 3,90 & 1,20 & $76 \%$ \\
\hline KP3 & melakukan kerjasama dengan pelanggan untuk pengemasan ramah lingkungan & 3,85 & 1,13 & $71 \%$ \\
\hline \multirow[t]{2}{*}{ KP4 } & melakukan kerjasama dengan pelanggan untuk menggunakan lebih sedikit energi selama transportasi & 4,05 & 0,63 & $83 \%$ \\
\hline & Pernyataan & Mean & Std. Dev & $\%$ skor $4-5$ \\
\hline \multicolumn{5}{|c|}{ PI - Pemulihan Investasi : Perusahaan kami .... } \\
\hline P1 & menjual kelebihan persediaan bahan & 2,88 & 1,14 & $39 \%$ \\
\hline $\mathrm{P} 2$ & menjual bahan bekas & 2,68 & 1,52 & $39 \%$ \\
\hline P3 & menjual kelebihan peralatan modal & 2,49 & 1,19 & $22 \%$ \\
\hline $\mathrm{P} 4$ & melakukan sistem daur ulang untuk produk cacat & 3,39 & 1,16 & $51 \%$ \\
\hline \multicolumn{5}{|c|}{ D - Desain Ramah Lingkungan } \\
\hline D1 & produk untuk mengurangi penggunaan bahan/energi & 3,90 & 0,74 & $78 \%$ \\
\hline $\mathrm{D} 2$ & produk untuk digunakan kembali dan didaur ulang. & 2,83 & 1,20 & $37 \%$ \\
\hline D3 & produk untuk menghindari penggunaan bahan berbahaya & 4,00 & 1,24 & $80 \%$ \\
\hline D4 & proses untuk meminimalkan limbah & 3,98 & 0,85 & $73 \%$ \\
\hline \multicolumn{5}{|c|}{ M - Manajemen Lingkungan Internal } \\
\hline 1 & Pimpinan puncak perusahaan kami berkomitmen untuk melakukan manajemen lingkungan & 4,05 & 0,59 & $85 \%$ \\
\hline 2 & Manajer/supervisor perusahaan kami mendukung manajemen lingkungan & 4,12 & 0,64 & $85 \%$ \\
\hline 3 & $\begin{array}{l}\text { Semua unit/bagian di perusahaan kami, bekerjasama melakukan perbaikan untuk mengurangi dampak } \\
\text { lingkungan }\end{array}$ & 3,95 & 1,02 & $83 \%$ \\
\hline 4 & Perusahaan kami melakukan pengendalian kualitas lingkungan secara menyeluruh & 3,78 & 1,11 & $73 \%$ \\
\hline 5 & Perusahaan kami melakukan program audit lingkungan & 3,44 & 1,03 & $54 \%$ \\
\hline 6 & Perusahaan kami melakukan sistem manajemen lingkungan & 3,73 & 0,84 & $63 \%$ \\
\hline
\end{tabular}

atribut ekologis dalam produk dan proses, serta tuntutan dari pemangku kepentingan di perusahaan untuk desain dan pengembangan produk.

3) Green supplier integration : melibatkan kolaborasi untuk tujuan lingkungan antara perusahaan utama dan pemasoknya dalam mengelola proses bisnis lintas perusahaan, termasuk berbagi informasi dan kemitraan strategis.

4) Green customer cooperation : melibatkan berbagi informasi strategis serta kolaborasi antara perusahaan dan pelanggan mereka, yang bertujuan untuk meningkatkan visibilitas dan memungkinkan perencanaan bersama untuk lingkungan.

5) Reverse logistics : terkait dengan tiga "Re" circular economy, yaitu mendaur ulang (recycling), menggunakan kembali (reuse), dan mengurangi jumlah bahan baku (reduce) dalam fase produksi atau pasca konsumsi.

\section{METODOLOGI PENELITIAN}

Penelitian ini dilakuan dengan metode survei menggunakan kuesioner. Kuesioer disebarkan baik melalui offline maupun online. Sebelumnya beberapa UKM telah dihubungi terlebih dahulu oleh peneliti untuk menanyakan kesediaannya menjadi responden. Lalu penyebaran secara offline dengan mendatangi lokasi UKM yang telah bersedia satu per satu. Pengumpulan data secara online dilakukan dengan google form. Penyebaran link kuesioner ini juga dilakukan dengan menghubungi UKM satu per satu terlebih dahulu. Jika responden tidak dapat ditemui secara langsung karena keterbatasan waktu dan tempat, maka akan diberikan kuesioner online pada link tersebut. Selain itu penyebaran secara online juga dilakakukan melalui email.

Item pengukuran yang digunakan untuk mengukur praktik GSCM diadaptasi dari penelitan Agarwal et.al.[17]. Item pertanyaan pada penelitian ini ditunjukkan pada masinngmasing tabel analisis deskriptif praktik GSCM. Skala yang digunakan dalam pengisian kuesioner adalah skala Likert 5 . Sampel penelitian ini adalah usaha kecil dan menengah (UKM) sektor manufaktur dan pada saat proses penelitian bersedia menjawab pertanyaan yang diajukan peneliti. UKM diwakili oleh pemilik atau pengelola (manajer) dalam pengisian kuesioner penelitian. Metode sampling yang digunakan adalah convenience sampling. Kuesioner disebar selama bulan Mei hingga Juni 2019 di Surabaya dan didapatkan 41 data kuesioner.

Analisis penelitian ini terdiri dari deskripsi demografi dan analisis deskriptif statistik praktik GSCM. Analisis deskriptif statistik praktik GSCM dilakukan dengan menghitung rata-rata jawaban responden pada setiap dimensi praktik GSCM. Serta dengan menghitung proporsi jawaban responden lebih dari 4 pada setiap item dimensi praktik GSCM. 


\section{ANALISIS DAN DISKUSI}

\section{A. Deskripsi Demografi}

Profil responden dideskripsikan berdasarkan jabatan di perusahaan, lama bekerja di perusahaan, sektor perusahaan manufaktur, hasil penjualan tahunan perusahaan, dan bentuk badan hukum perusahaan. Profil responden ditunjukkan pada Tabel 2.

Jabatan responden penelitian ini dikelompokkan menjadi dua, yaitu pemilik dan pengelola. Pemilik maupun pengelola, keduanya dianggap sebagai seorang pimpinan pada masingmasing UKM. Sebanyak 28 responden (68\%) adalah pemilik usaha. Sedangkan 13 responden lainnya (32\%) sebagai pengelola atau manajer. Semua responden dalam penelitian ini dianggap memahami kondisi usahanya serta memiliki pengaruh besar terhadap kebijakan usaha kedepannya.

Lama responden bekerja, dikempokkan menjadi lima jangka waktu. Mayoritas responden yaitu sebanyak 16 orang (39\%) telah berkerja di perusahaan selama 6-10 tahun. Pada Tabel 2. menunjukkan responden lebih banyak yang bekerja kurang dari 10 tahun. Hanya satu responden yang telah bekerja di perusahaan selama lebih dari 20 tahun.

Sektor usaha penelitian ini dikhususkan untuk industri manufaktur atau pengolahan. Responden yang paling banyak adalah usaha pengolahan produk makanan dan minuman yaitu sebanyak 20 UKM (49\%). Selain itu juga terdapat responden dengan kelompok sektor pengolahan produk tekstil, pakaian, alas kaki, dan kulit sebanyak 10 (24\%); produk kayu dan kertas sebanyak 5 (12\%); dan sektor produksi lainnya sebanyak $6(15 \%)$, antara lain produk plastik, tas, souvenir boneka, dan kosmetik.

Hasil penjualan tahunan dapat digunakan untuk mengetahui skala usaha menurut Undang-Undang. Usaha yang dapat menjadi responden penelitian ini hanya usaha kecil dan menengah (UKM). Sebanyak 35 (85\%) responden merupakan usaha kecil dengan hasil penjualan pertahun sebesar Rp 300 juta sampai $\mathrm{Rp} 2,5$ miliar. Sisa responden lainnya yaitu sebanyak 6 UKM (15\%) memiliki penjualan tahunan sebesar Rp 2,5 miliar sampai Rp 50 miliar, yang berarti tergolong usaha skala menengah.

Sebagian besar UKM yang menjadi sampel penelitian ini merupakan perusahaan perseorangan UD yaitu sebanyak 20 responden $(49 \%)$. Sedangkan $8(20 \%)$ responden memiliki bentuk badan usaha berupa $\mathrm{CV}$, dan 13 responden lainnya tidak berbadan usaha.

\section{B. Analisis Deskriptif Praktik GSCM}

Analisis deskriptif statistik dilakukan pada lima dimensi pada praktik GSCM. Berikut merupakan hasil analisis deskriptif statistik pada masing-masing variabel. Pada Tabel 3. menunjukkan item pertanyaan praktik GSCM beserta nilai rata-rata, standar deviasi, dan presentase jawaban lebih dari 4 untuk masing-masing item.

\section{1) Pembelian Ramah Lingkungan}

Pada Error! Reference source not found.3, menunjukkan bahwa UKM cukup setuju bahwa perusahaannya melakukan pembelian ramah lingkungan. Hal tersebut dapat dilihat melalui rata-rata jawaban responden pada pernyataan dimensi pembelian ramah lingkungan memeiliki skor diatas tiga. Ratarata terbesar pada dimensi pembelian ramah lingkungan adalah item indikator PR3, yaitu sebesar 3,93. Hal ini menunjukkan bahwa dari segi pembelian ramah lingkungan, rata-rata UKM melakukan kerjasama dengan pemasok untuk tujuan ramah lingkungan.

Dari perhitungan jumlah responden yang menjawab dengan skor 4 dan 5, didapatkan hasil bahwa persentase tertinggi pada dimensi ini adalah item PR6, yaitu 73\%. Hal ini menunjukkan bahwa dari aspek pembelian ramah lingkungan, lebih banyak UKM yang telah menjadikan ramah lingkungan sebagai salah satu kriteria dalam pemilihan pemasok.

\section{2) Kerjasama Pelanggan untuk Persyaratan Lingkungan}

Nilai rata-rata dan presentase skor untuk empat indikator pada variabel kerjasama pelanggan (KP) tidak menunjukkan perbedaan yang signifikan. Rata-rata responden setuju bahwa perusahaannya melakukan kerjasama dengan pelanggan untuk lingkungan. Rata-rata tertiggi yaitu perusahaan menerima masukan dari pelanggan untuk mendesain produk yang ramah lingkungan. Dari hasil proporsi skor $\geq 4$, juga menunjukkan hasil serupa, bahwa item KP1 adalah yang paling banyak dilakukan oleh UKM. Tingginya presentase ini menunjukkan bahwa praktik GSCM dalam hal kerjasama pelanggan untuk lingkungan, telah banyak dilakukan oleh UKM.

\section{3) Pemulihan investasi}

Dimensi pemulihan investasi menunjukkan nilai rata-rata yang rendah. Hal ini menunjukkan bahwa mayoritas UKM pada penelitian ini tidak setuju bahwa perusahaannya melakukan pemulihan investasi seperti menjual kelebihan persediaan, menjual bahan bekas, dan menjual kelebihan peralatan modal. Meskipun sebanyak 51\% UKM yang telah melakukan sistem daur ulang untuk produk yang cacat di perusahaannya. Nilai standar deviasi pada dimensi dukungan teknologi berada pada kisaran 1,14 hingga 1,52. Hal tersebut menunjukkan bahwa terdapat variasi jawaban responden yang tinggi dalam melakukan pemulihan investasi.

\section{4) Desain ramah lingkungan}

Nilai rata-rata pada dimensi desain ramah lingkungan hampir semua mendekati angka 4, kecuali item D2. Pada item indikator D2 menunjukkan rata-rata persentase skor 4-5 yang paling rendah. Menunjukkan bahwa perusahaan cenderung tidak mendesain produknya untuk dapat digunakan kembali dan didaur ulang. Hal ini bisa terjadi karena mayoritas UKM yang menjadi responden penelitian ini adalah sektor manufaktur produk makanan dan atau minuman. Makanan dan minuman merupakan barang konsumsi yang digunakan langsung habis dan setelahnya tidak dapat digunakan lagi.

\section{5) Manajemen lingkungan internal}

Secara keseluruhan UKM setuju bahwa perusahaannya melakukan manajemen lingkungan internal. Hal tersebut dapat dilihat melalui rata-rata jawaban responden pada pernyataan dimensi pembelian ramah lingkungan yang cukup tinggi. Ratarata terbesar pada dimensi manajemen lingkungan internal adalah item dukungan manajer dan, yaitu 4,12. Hal ini juga 
ditunjukkan dari persentase skor 4 dan 5 tertinggi terdapat pada item M1 dan M2. Berarti sudah banyak manajemen puncak UKM komitmen dan mendukung manajemen lingkungan di perusahaannya. Namun masih sedikit UKM yang melakukan program audit lingkungan pada perusahaannya.

\section{SIMPULAN DAN SARAN}

\section{A. Simpulan}

Penelitian ini memberikan informasi mengenai praktik green supply chain management pada usaha skala kecil dan menengah. Hasil penelitian ini menunjukkan bahwa UKM manufaktur di Surabaya sudah melakukan beberapa praktik GSCM pada perusahaannya, meskipun tidak secara keseluruhan. Praktik GSCM yang paling banyak dilakukan oleh UKM adalah bekerjasama dengan pelanggan untuk persyaratan lingkungan. Namun masih sedikit UKM yang melakukan pemulihan investasi.

Penelitian ini dapat digunakan oleh stakeholder terkait untuk dapat menyusun strategi peningkatan pelaksanaan praktik GSCM pada UKM, khususnya di Surabaya. Namun strategi tersebut juga perlu didukung dengan mengetahui faktor-faktor yang membuat UKM melakukan praktik GSCM. Sehingga diharapkan dapat tercapainya tujuan bersama, yaitu untuk menjaga lingkungan dengan meminimalkan potensi UKM merusak lingkungan.

\section{B. Saran}

Didalam penelitian ini memiliki keterbatasan waktu pengumpulan data yang singkat dan terbatas sehingga skala wilayah penelitian ini hanya di kota Surabaya saja, sehingga terdapat kemungkinan bahwa belum sepenuhnya mewakili UKM daerah lain di Indonesia atau kondisi di negara-negara lain. Oleh sebab itu, disarankan kepada penelitian selanjutnya untuk melibatkan sektor dan daerah yang lebih luas seperti tingkat regional ataupun nasional, sehingga diperoleh hasil penelitian yang lebih general

\section{DAFTAR PUSTAKA}

[1] Conserve Energy Future, "Current Environmental Issues," www.conserve-energy-future.com, 2019. .

[2] Tribuntravel.com, "2019 Diprediksi Jadi Tahun Terpanas Karena El Nino dan Pemanasan Global," http://travel.tribunnews.com, 2019. .

[3] metro.tempo.co, "Buih Putih Seperti Salju Muncul di Kali Bekasi," 2018.

[4] Conserve Energy Future, "Industrial Pollution," www.conserve-energyfuture.com, 2019. .

[5] Undang-Undang No 3 Tahun 2014 Tentang Perindustrian. Republik Indonesia.

[6] Z. Wang, Q. Wang, S. Zhang, and X. Zhao, "Effects of customer and cost drivers on green supply chain management practices and environmental performance," J. Clean. Prod., vol. 189, pp. 673-682, 2018, doi: 10.1016/j.jclepro.2018.04.071.

[7] L. V. J. T. G. Agarwal, "Green supply chain management practices and performance: the role of firm-size for emerging economies," J. Manuf. Technol. Manag., vol. 28, no. 3, 2017, doi: http://dx.doi.org/10.1108/JMTM-09-2016-0123 Downloaded.

[8] Undang-Undang No 20 Tahun 2008 Tentang Usaha Mikro, Kecil dan Menengah, no. 1. Republik Indonesia, pp. 1-31.

[9] BPS Provinsi Jawa Timur, "Jumlah UMKM dan Naker 38 Kab Kota (Rekap)," 2012. .

[10]D. E. Issetiabudi, "Pencemaran Lingkungan Tinggi," Kementrian Perindustrian Republik Indonesia, 2014.

[11]R. Maria, A. Rahmat, and N. Sumawijaya, "Potensi pencemaran air tanah dangkal dari limbah industri pencelupan," in Prosiding Pemaparan Hasil Penelitian Puslit Geoteknologi - LIPI, 2013, pp. 978-979.

[12] Setiyono and S. Yudo, "Potensi pencemaran dari limbah cair industri pengolahan ikan di kecamatan Muncar, kabupaten Banyuwangi," J. Air Indones., vol. 4, no. 2, pp. 136-145, 2008.

[13]I. N. Pujawan and E. Mahendrawathi, "Supply Chain Management." Penerbit Andi, Yogyakarta, 2017.

[14]S. Azari, "Pengelolaan Risiko pada Green Supply Chain Management dengan Metode House Of Risk: Studi Kasus di PT Petrokimia Gresik," Institut Teknologi Sepuluh Nopember, 2018.

[15]J. Roehrich, S. U. Hoejmose, and V. Overland, "Driving green supply chain management performance through supplier selection and value internalisation: a self-determination theory perspective," Int. J. Oper. Prod. Manag., vol. 37, no. 4, 2017, doi: http://dx.doi.org/10.1108/IJOPM-09-2015-0566.

[16]Q. Zhu and J. Sarkis, "Green supply chain management in China: pressures, practices and performance," vol. 25, no. 5, pp. 449-468, 2005, doi: 10.1108/01443570510593148.

[17]A. Agarwal, F. Giraud-carrier, and Y. Li, "A Mediation Model of Green Supply Chain Management Adoption: The Role of Internal Impetus," Int. J. Prod. Econ., 2018, doi: 10.1016/j.ijpe.2018.09.011. 